\title{
GEOTECHNOLOGIES FOR THE CHARACTERIZATION OF SPECIALTY COFFEE ENVIRONMENTS OF MANTIQUEIRA DE MINAS IN BRAZIL
}

\author{
H. M. R. Alves ${ }^{\text {a }}$, T. G. C. Vieira ${ }^{\text {b }}$, M. M. L. Volpato ${ }^{\text {b }}$ M.P. C. Lacerda ${ }^{c}$, F. M. Borém ${ }^{d}$ \\ aEMBRAPA CAFÉ, Laboratório de Geoprocessamento, Epamig Sul, 37200-000, Lavras, MG, Brasil - helena.alves@embrapa.br \\ bEPAMIG SUL, Laboratório de Geoprocessamento, 37200-000, Lavras, MG, Brasil -tatianagcvieira@gmail.com, \\ margarete@epamig.ufla.br \\ cUnB, Faculdade de Agronomia e Veterinária, 70910-900, Brasília, DF, Brasil - marilusa@ unb.br \\ dUFLA, Departamento de Engenharia, 37200-000, Lavras, MG, Brasil - flavioborem@ deg.ufla.br
}

\section{Commission VIII, WG VIII/8}

KEY WORDS: Remote Sensing, Coffee, Environmental Characterization, Geotechnology, Geographic Indication

\begin{abstract}
:
Land-use/land-cover change (LUCC) is a major cause of environmental transformation. Distant drivers, often associated with emerging markets for specific products, are now being considered one of the main factors of LUCC and are gaining attention in land change science. Consumers show an increasing interest in local and quality food, certified for its origin and its environmental production standards. A kind of agricultural product certification, Geographic Indication, identifies a product as originating from a specific region where a given quality, reputation or characteristic is attributed to its geographical origin. Sustainable land use is potentially an indirect effect of Geographic Indication, as it requires better land management in order to preserve the natural resources associated with the unique characteristics of the certified product. Located in the southern region of the state of Minas Gerais in Brazil is the region of Mantiqueira de Minas, considered one of the most important regions for the production of specialty coffees in Brazil. In 2011, the region's tradition and reputation were recognized with a Geographic Indication, the second given for coffee regions in the country. To explore the full potential of this area for producing coffees with higher quality and meet the growing demand of this new international market, which aggregates value at specialty coffees, it became fundamental to understand the coffee environments of the region, the "terroirs" where these coffees are obtained. Geotechnology can give a significant contribution in filling this gap. This work is part of a research project that made a detailed characterization of the region's coffee agroecosystems. Geotechnologies were employed to map the areas occupied by coffee plantations by using RapidEye satellite images and SPRING and ArcGIS software. All the segments of the environment were characterized and mapped in detail and the relations with coffee quality were evaluated. The results showed that coffee occupies approximately $8 \%$ of the region's total area and is mostly distributed in the hilly areas with higher elevations. They also proved that specialty coffees are more likely to be obtained in altitudes above $1100 \mathrm{~m}$, also being correlated to genotype and to the post-harvest methods employed. These results provide information that allows a better understanding of the factors involved in the expression of coffee quality. They also provide the scientific basis required for obtaining a new Geographic Indication for the Mantiqueira de Minas region, this time a Denomination of Origin (DO), which will certainly aggregate value to the specialty coffees produced in this unique region.
\end{abstract}

\section{INTRODUCTION}

Mapping the dynamics of land use and cover is essential to the planning and management of geographic space. Among the more recent applications of agricultural mapping and characterization are the Geographic Indications (Indicação Geográfica - $I G$ ). In this scenario, where the productive sector and the market establish a transparent relationship based on free choice on the consumer's part and a differentiated price or added value based on the product's quality, IGs reflect a new production philosophy, more centred on quality, specialty and uniqueness, all of which stem from the point of origin of the product.

In Brazil, coffee is one of the agricultural products with highest potential for IG. The international coffee market has signalled a growing demand for specialty coffees, whose characteristics are related to the product's geographic environment. Brazil, the biggest producer and second biggest consumer of coffee in the world, has been responding to this new demand. Coffee ranks second in Brazil's agricultural exports, and it is one of the most important sources of revenue for the Brazilian economy. Minas Gerais state is the country's main producer and it's southern region (Sul de Minas), with an estimated planted area of 600,000 hectares, is the biggest coffee production region in the whole country.

Due to its size, the Sul de Minas region presents edaphoclimatic variations that result in coffees with distinctive characteristics. Within this region is the Mantiqueira de Minas, an area whose specialty coffees have been distinguished for their high sensorial quality. This quality has been increasingly acknowledged in the international market, which ranks these coffees among the best in the world.

The Brazilian legislation allows for two types of Geographic Indication, the Indication of Origin (Indicação de Prodedência - IP) and Denomination of Origin (Denominacao de Origem $D O)$. The IP is the geographic name of a particular region or territory that became known and prominent for a specific product. In the DO, on the other hand, apart from tradition and notoriety, the geographic name also designates a product whose 
qualities or characteristics rely exclusively or essentially on the geographic environment.

The characterization of the coffee agroecosystems in the Mantiqueira de Minas is essential for planning and development of the area. Mapping its coffee lands and delimiting the terroirs with potential for producing specialty coffees can enhance the competitiveness and sustainability of the production chain. In Brazil, detailed characterizations of its natural resources are still lacking, and it is here that geotechnologies and computer systems can play an important role (Moreira et al., 2004; Vieira et al., 2007).

The aim of this work was to map the land use/land cover in the area recently demarcated as Mantiqueira de Minas using geotechnologies to delimit its coffee lands.

\section{MAIN BODY}

The Mantiqueira de Minas area (Figure 1) encompasses 25 municipalities, located in the Sul/Southeast physiographic zone of Minas Gerais state in a rectangle at $21^{\circ} 39^{\prime} 43^{\prime \prime} / 22^{\circ} 46^{\prime} 10^{\prime \prime} \mathrm{S}$ latitude and $46^{\circ} 2^{\prime} 20^{\prime}$ ' $/ 44^{\circ} 34^{\prime} 28^{\prime}$ 'O longitude.

The area belongs to the Rio Grande basin and is crossed by the Sapucaí, Verde and Grande rivers. It's territorial expanse is approximately $6,300 \mathrm{KM}^{2}$ with altitudes between 801 and 2,252 meters, mean annual temperature of $17.9^{\circ} \mathrm{C}$ and mean annual rainfall of $1665 \mathrm{~mm}$ (IBGE, 2016).

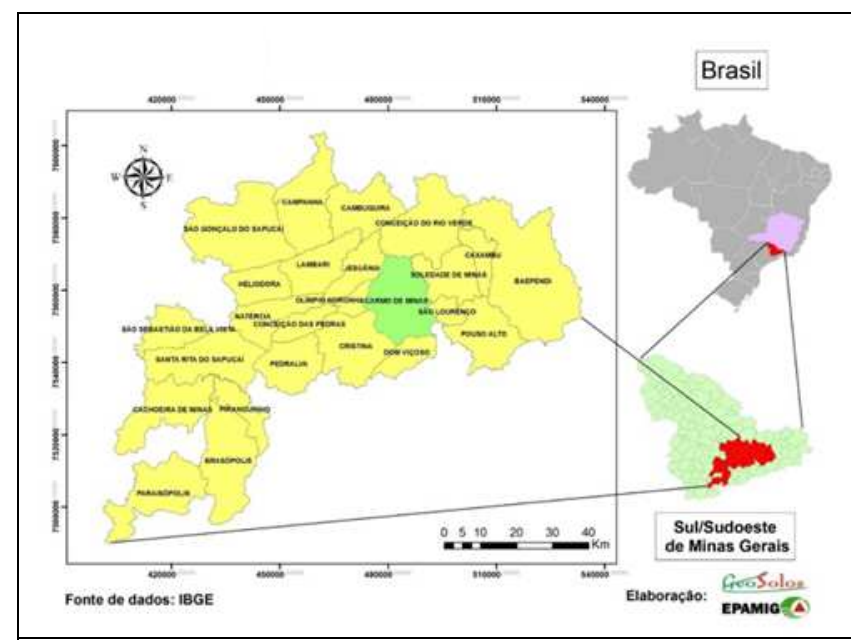

Figure 1. Location of the municipalities that constitute the IG Mantiqueira de Minas in the state of Minas Gerais and Brazil.

RapidEye satellite images were used to map the land uses. The scenes with less cloud cover from 2009 were selected. The original spatial resolution of each band is 6.5 meters, but after the ortoretification each band was re-sampled to a 5 meter resolution, resulting in corrected images whose precision is compatible with a 1:25.000 scale.

The digital processing of the images, vetorization of the thematic maps and visual interpretation were done in SPRING (Câmara et al., 1996) and ArcGis (ESRI, 2008). A georeferenced mosaic of the RapidEye images were generated. The images were segmented and their visual interpretation/classification carried out through simultaneous observation of discerning elements such as tone, colour, texture, shape, size, pattern, shade, as described by Marchetti and Garcia (1996).

The current land use/cover was mapped in the following classes; Coffee: coffee fields in different stages of development; Forest: areas occupied by natural vegetation with varying size and type, including riparian vegetation, patches of Atlantic forest and cerrado; Urban Area: cities and rural villages; Water: rivers, lakes, dams and other water bodies; Other Uses: pasture, natural fields and areas destined for annual crops; Reforestation: commercial forest. The mapping was checked in the field. A sample of 948 points, collected in all the classes mapped, were georeferenced and cheked during the field work.

The thematic land use/cover map is shown in Figure 2, and Table 3 presents the quantification of the land use/cover classes. The total area mapped is 630,713 ha, of which 52,790 are coffee lands. The remaining classes mapped represent the following percentages in relation to the total area: Water: $0.44 \%$; Urban Area: $0.93 \%$; Forest: $19.34 \%$; Other Uses: $70.29 \%$. The accuracy of the map was assessed by comparison with the points georeferenced in the field work. A Kappa index of $90.2 \%$ and a Global index of 0.86 were obtained, both considered good. These indexes are based on an error matrix, which constitutes a way of representing the accuracy of a set of simulated or estimated data in relation to a reference. All of the classes had a high acuracy. For the Coffee class, $89.66 \%$ of the points mapped as coffee fields were accurately represented in the thematic map generated from the classification of the satellite images (Congalton, 1991; Bernardes, 2006; Figueiredo and Vieira, 2007; Vieira et al., 2009).

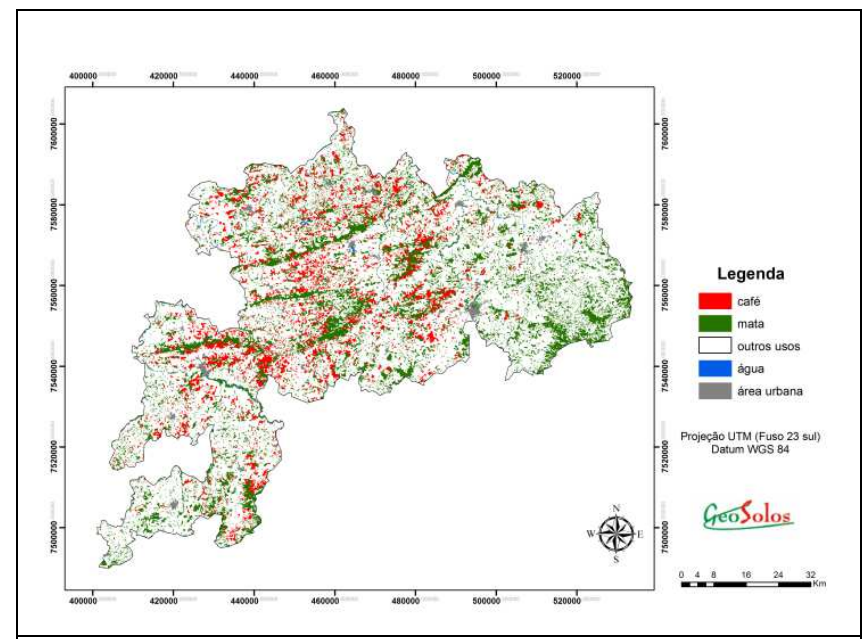

Figure 2. Land use/land cover map of the IG Mantiqueira de Minas.

\begin{tabular}{|l|c|}
\hline Land use/land cover classes & Area occupied (\%) \\
\hline & \\
Water & 0.44 \\
Urban area & 0.93 \\
Coffee & 8,33 \\
Forest & 19.34 \\
Other uses & 70.29 \\
\hline
\end{tabular}

Table 3. Land use/land cover occupation in region of Mantiqueira de Minas. 


\section{CONCLUSIONS}

The RapidEye images and the methodology used were efficient in mapping the land use and cover in the study area. The spatial and radiometric resolution of the RapidEye images guaranteed a satisfactory distinction of the land use and cover classes selected.

The results of this work provide an important basis for understanding the factors involved in the expression of the beverage quality of the coffees produced in the area. From the environmental characterization, it is possible to understand the spatial and temporal dynamic of the area's coffee lands, establish the relation between quality of the product and the environment and to provide the scientific grounding required to obtain a Denomination of Origin for the specialty coffees produced in the area.

\section{ACKNOWLEDGEMENTS}

The authors would like to thank FAPEMIG, Consorcio Pesquisa Cafe and $\mathrm{CNPq}$ for financing the work and for the research fellowships that made it possible.

\section{REFERENCES}

Bernardes, T. 2006. Caracterização do ambiente agrícola do complexo Serra Negra por meio de Sensoriamento Remoto e Sistemas de Informação Geográfica. 2006. Dissertação (Mestrado em Ciência do Solo) Lavras: Universidade Federal de Lavras, 119p.

Câmara, G.; Souza, R. C. M.; Freitas, U. M.; Garrido, J. 1996. SPRING: Integrating remote sensing and GIS by objectoriented data modelling. Computers \& Graphics, 20(3), pp. 395-403.

Congalton, R. G. 1991. A review of assessing the accuracy of classifications of remotely sensed data. Remote Sensing of Environment, 49(12), pp. 1671-1678.

ESRI. Enviromental System Research Institute. 2008. ARC/INFO V.9.3.0 (computer program). ESRI, Readlands.

Figueiredo, G. C.; Vieira, C. A. O. 2007. Estudo do comportamento dos índices de Exatidão Global, Kappa e Tau comumente usados para avaliar a classificação de imagens do sensoriamento remoto. In: Simpósio Brasileiro de Sensoriamento Remoto, Florianópolis, Brasil, Vol. XIII, pp. 5755-5762.

IBGE, 2016. Instituto Brasileiro de Geografia e Estatística. http://www.ibge.gov.br/home/mapa_site/mapa_site.php\#geocie ncias (17 April 2016)

Marchetti, D. A. B.; Garcia G. J. 1996. Princípios de fotogrametria e fotointerpretação. Nobel, São Paulo, 264p.

Moreira, M. A.; Adami, M.; Rudorff, B. F. T. 2004. Análise espectral e temporal da cultura do café em imagens Landsat. Pesquisa Agropecuária Brasileira, 39(3), pp.223-231.

Vieira, T. G. C.; Alves, H. M. R.; Bertoldo, M. A.; Souza, V. C. O. 2007. Geothecnologies in the assessment of land use changes in coffee regions of the state of Minas Gerais in Brasil. Coffee Science, 2(2), pp.142-149.

Vieira, T. G. C., Alves, H. M. R., Volpato, M. M. L., Bernardes, T., Santos, E. R. 2009. Avaliação de classificadores automáticos no mapeamento de áreas cafeeiras da região de Guaxupé, Minas Gerais. In: Simpósio de Pesquisa dos Cafés do Brasil, Vitória, Brasil, Vol. VI, http://www.sbicafe.ufv.br/bitstream/handle/123456789/2631/11 1.pdf?sequence=1\&isAllowed=y (22 April 2013). 